\title{
Diskussie
}

\section{Montessori-skole: die ander kant}

\section{Monica Viljoen \\ FOCHVILLE}

$\mathrm{Na}$ aanleiding van die artikel "Die invloed van die New Age-beweging op die onderwysagenda van die toekoms" deur Lien van Niekerk en Corinne Meier van die Departement Historiese Opvoedkunde van Unisa (vgl. Koers, 59 (1) 1994:6984) wil ek graag 'n ander sy van Montessori-skole onder die aandag van Koerslesers bring.

\section{- Dr. Montessori - akademiese belangstellingsveld}

Dr. Montessori het 'n baie sterk akademiese agtergrond gehad. Sy was die eerste Italiaanse vrou wat as 'n mediese dokter gekwalifiseer het. Dit was egter net die begin; sy het ook verder studeer in die Filosofie, Sielkunde, Pedagogiek en Antropologie. Sy het ook die volgende posisies beklee: Chair of Hygiene aan die Magistero Femminite in Rome. Verder was sy permanente eksterne eksaminator in die Fakulteit Pedagogiek. Sy was ook vir vier jaar profesor by die Universiteit van Rome by die Fakulteit Pedagogiese Antropologie. Ook was sy die Direkteur van die Orthophrenic Institute waar sy baie navorsing gedoen het oor verstandelik vertraagde kinders. Bo en behalwe hierdie akademiese verbintenisse het sy 'n privaat mediese praktyk bedryf en dikwels as spreker opgetree by kongresse vir vroueregte. Die twee mense wat die grootste invloed op haar gehad het, was eerstens Jean Itard (1774-1834), 'n Franse mediese dokter wat gespesialiseer het in oor, neus en keel. Hy het studies onder inboorlinge gedoen met die oog op inligting oor taalontwikkeling en het veral bekendheid verwerf met sy studies van die wolfseun wat in 'n woud ontdek is. Hieroor het 'n boek verskyn met die titel The Care and Education of the Wild Boy of Aveyron. Ook het dr. Montesorri die werke van Edouard Sequin (1772-1840) bestudeer. Sequin het naamlik beroemd geword vir sy werk wat hy met die verstandelik vertraagde kinders gedoen het. Sy werk is weergegee in 'n boek getiteld Traitment Moral, Hygiene et education des Idiots.

Ons kan dus die afleiding maak dat haar belangstellings baie wyd gestrek het en alhoewel sy reeds in haar sestigerjare was met die ontwaking van die Teosofie, sou sy waarskynlik kennis daarvan geneem het. Alhoewel sy nog steeds werke 
gepubliseer het tot feitlik voor haar dood, verskyn daar geen aanhalings of verwysings na Helena Blavatsky in hierdie werke nie. In haar publikasies verskyn egter verskeie aanhalings uit die Bybel. Dr. Montessori het ook 'n boek geskryf oor The Child in the Church (1930). In die lig van die lys publikasies van $\mathrm{dr}$. Montessori is dit opvallend dat die bronnelys van die artikel van Lien van Niekerk en Corinne Meier nie een publikasie deur dr. Montessori insluit nie.

\title{
- Houding teenoor fantasieverhale
}

Dit kan kategories gestel word dat fantasieverhale geen plek het in die Montessori-metode nie. Maria Montessori was uitgesproke gekant teen fantasieverhale omdat dit verwarrend is vir kinders jonger as ses jaar omdat hulle nog nie die vermoë het om te onderskei tussen reg en verkeerd of tussen fantasie en die werklikheid nie.

\section{- Montessori se siening van inkarnasie}

Dr. Montessori verwys wel na inkarnasie, maar in 'n totale ander raamwerk as waarna in die artikel verwys word. Volgens dr. Montessori vind inkarnasie plaas wanneer die fisiese en psigiese elemente van die kind begin saamsmelt - dit is wanneer die kind kan begin verstaan en kommunikeer met mense om hom en sy bewegings meer doelgerig raak. Om hierdie stelling te illustreer, gee ek 'n uittreksel uit die boek Maria Montessori, Her Life and Work (1957) van E.M. Standing.

\begin{abstract}
The important thing for us to realise says Montessori, is that in the twofold development which now takes place (the completion of the body on the one hand, and the creation for the mental faculties on the other) it is the mind rather that the body which sets the tune. The human soul is not united to its physical vehicle in a ready-made relationship which exists at birth, as in the case of animals who merely 'incarnate the instincts of their species'. Hence the whole drama of these early years, in human development, lies in the effort to achieve what Montessori calls a 'progressive incarnation' in which spirit and flesh are brought into an ever more perfect harmony.
\end{abstract}

Daar moet dus duidelik onderskei word tussen inkarnasie en reïnkarnasie

\section{- Montessori, Hitler en Mussolini}

Wat was die verhouding tussen Montessori, Hitler en Mussolini? Hulle het aanvanklik saam gewerk, maar daar word nagelaat om te noem dat hulle later meer uiteenlopende sieninge gehad het, dat dr. Montessori se skole gesluit is en sy uiteindelik 'n uitgewekene uit Italië was. Die uittreksel uit die boek The Essential Montessori deur Elisabeth Hainstock (1986) gee 'n breë oorsig oor die verloop van daardie tydperk. 
Hitler and Mussolini were both interested in the method as adaptable to mass education, a means of creating a new social order through the education of the infant. Montessori was always eager to have people adopt her method, but she did not agree with this particular end result. Those who knew her claimed she was apolitical. Italy was her home, with or without Mussolini, and it was possible then to live under Fascism if you did not openly oppose it. Mussolini became the President of the Montessori Society of Italy and Montessori schools abounded. By 1934, however, friction had developed between Dr Montessori and Mussolini's leaders. World War II was to bring many changes to the movement throughout the world.

In 1935, the Montessori method was forbidden in Germany by Nazi police, and by 1936, all of the schools in Italy had also closed. Montessori first went to Barcelona but then fled to England when the Civil War broke out in Spain, arriving in time to preside as President of the fifth International Montessori Congress. When Hitler marched into Vienna in 1938, the existing Montessori schools there were also shut down

\section{- Maria Montessori se siening van die kosmos}

Sy was baie bewus van die natuurlike omgewing en die verhouding tussen die lewende wesens en hulle omgewing, asook die bydrae van die mens tot die behoud van die spesies - 'n aspek wat sy beskryf as die kosmiese plig van die mens. Vandag, veertig jaar later, is ons almal terdee bewus van die natuurlike ekwilibrium en die gevolge van alle vorme van besoedeling op ons voortbestaan. Sy het toe reeds besef dat die kind 'n natuurlike behoefte het ten opsigte van sy oriëntering tot die kosmos. Die kind wil weet waar sy plek is teenoor die plante, diere, ander nasies en selfs die sterrestelsel. Veral in die tydperk 6-12 jaar is die kind besonder geïnteresseerd daarin - Maria Montessori inkorporeer hierdie faset reeds in die voorskoolse fase. Apparaat bestaan onder meer uit legkaarte van verskillende lande, landsvlae, plante en diere. Haar metode maak dus ruim voorsiening vir aardrykskunde.

\section{- Die didaktiese toepassing van die Montessori-metode}

'n Verdere aspek van die Montessori-metode wat ek wil beklemtoon, is die didaktiese toepassing van die metode deur die onderwyser (sy verkies die benaming directress) in die klaskamer of opvoedingsomgewing. Maria Montessori glo dat die kind sy eie onderwyser is. Die onderwyser se rol is om te sorg vir 'n goedversorgde, goed toegeruste, stimulerende omgewing. Die onderwyser stel die kind bekend aan die verskillende apparaat en die kind verkry dan die kennis deur selfontdekking - elkeen volgens sy eie vermoëns en ritme. Die onderwyser is dus die skakel tussen die kind en sy omgewing en neem nooit so 'n prominente plek in soos met meer tradisionale onderwysmetodes nie. Die kanse vir 'n Montessori-onderwyser om 'n hele klas in 'n spesifieke rigting te indoktrineer is dus skraler 
as in enige ander onderwysmetode. Daar word slegs per geleentheid met klein groepies van vyf of hoogstens agt kinders gewerk wanneer sang, liggaamsbewegings, die vertel van stories ensovoorts betrek word in die oordra van inligting.

\section{- Die ontwikkeling van die Montessori-metode}

Ons moet egter begrip hê vir die wyse waarop die Montessori-metode ontstaan het. In teenstelling met mense soos Dewey en Froebel wat 'n teorie ontwikkel het en dit dan toegepas het, het Maria Montessori sonder ' $n$ teorie begin. In haar eerste skool, Casa dei Bambini in Rome, moes sy toesig hou oor 'n groep kinders van verarmde, ongeletterde ouers. Met haar agtergrond van wetenskaplike navorsing het sy deur fyn waarneming die kinders se natuurlike reaksies en behoeftes bestudeer, en na aanleiding daarvan haar metode ontwikkel en geformuleer. Met hierdie metode het sy die basiese natuur van die mens betrek - met die gevolg dat dit met sukses oor die hele wêreld toegepas word deur alle volke en kulture.

Montessori-skole kan dus glad nie net summier geklassifiseer word as New Ageskole nie. Dit is moontlik dat 'n Montessori-skool deur die New Age-beweging gekaap kan word, maar nie in 'n groter mate as enige ander skole nie. Dit is dus die ouers se plig om die onderrigmetode van die skool waarin sy kinders is te ondersoek, watter onderwysmetode ook al gebruik word. Die Montessori-metode is ' $n$ baie goeie metode om toe te pas in ons land met sy vele kulture en nuwe aanpassings, juis omdat dié metode geskool is op die mens se basiese universele natuur en dus die kind sy individualiteit laat behou.

Die Montessori-metode beklemtoon inderdaad die aangebore goedheid van die kind. Die spontane aard van ontwikkeling bring die selfontdekking van kennis mee - ' $n$ faktor wat weer 'n goeie selfbeeld en selfdissipline tot gevolg het. Dit is belangrik om in gedagte te hou dat spontane denke ontwikkel tot kreatiewe denke en dit is sekerlik 'n doelwit waarna opvoedkundiges vandag strewe. 